\title{
Enhancing Seed Germination and Seedlings Development of Common Bean (Phaseolus vulgaris) by $\mathrm{SiO}_{2}$ Nanoparticles
}

\author{
Abdullah Alsaeedi ${ }^{1}$, Hassan El-Ramady ${ }^{2}$, Tarek Alshaal ${ }^{2 *}$, Mahdi Almohsen ${ }^{3}$ \\ ${ }^{1}$ Department of Environment and Natural Resources, Faculty of Agriculture and \\ Food Science, King Faisal University, Saudi Arabia, ${ }^{2}$ Department of Soil and \\ Water, Faculty of Agriculture, Kafrelsheikh University, Egypt and ${ }^{3}$ Ministry of \\ Education, Saudi Arabia
}

\begin{abstract}
$\mathbf{W}^{\mathrm{t}}$ Still lack knowledge concerning the mode of action of engineered nanoparticles in agriculture. The key point of this study is to investigate the role of nano-silica (NS) to enhance the seed germination and growth development of common bean. Four different concentrations of NS suspensions $\left(100,200,300\right.$, and $\left.400 \mathrm{mg} \mathrm{L}^{-1}\right)$ were supplemented to nursery and growth media. Our results showed that $300 \mathrm{mg} \mathrm{L}^{-1}$ of NS increased the final germination percentage from 82.3 to $97.7 \%$, the germination speed from 24.9 to $36.2 \%$ / day, the vigour index from 14.3 to 20.2, and decreased the mean germination time from 4.3 to 3.3 days. Strikingly, $300 \mathrm{mg} \mathrm{L}^{-1}$ of NS increased the root dry mass of common bean seedlings by $93.5 \%$,the shoot dry mass by $78.7 \%$, the root length by $32.7 \%$, and the shoot length by $13.2 \%$ versus untreated seedlings. This study proved that NS is able to improve the germination and growth of common bean as a result for altering some physiochemical reactions after penetrating the seed coat.
\end{abstract}

Keywords: Nano-silica, Seed germination, Growth dynamic, Common bean

\section{Introduction}

Common bean is widespread cultivated everywhere around the world as a major food legume except in Antarctica. This illustrates the ability of common bean on growth under different environmental conditions (Moreno-Limón et al., 2000). The world produces annually more than 6.8 million tons of green beans from a total area of 960,272 ha (FAO 2009). As a consequence of its high protein content, common bean is the fourth resource of protein supply all over America (Romero et al., 2013), and it is considered one of the most important ingredients of the Brazilian diet (Borém and Carneiro, 1999) beside being a valuable food plant for humans and nutritious fodder for animals as a result of its high protein and carbohydrate contents. As a good source of iron (Borém and Carneiro, 1999), common bean plays a vital role in the reclamation of marginal lands (nutrient-poor soils) due to its ability to fix the atmospheric nitrogen via symbiotic association with rhizobia (Alexander, 1984).

Silicon ( $\mathrm{Si}$ ) is the second abundant element in the Earth's crust after oxygen, and it is immobile in plants. Although, silicon is not classified as an essential nutrient for plants, its role in plant physiology and thus in plant growth particularly under biotic and abiotic stresses has been well documented (Khan et al., 2016). Several literatures have reported that silicon could ameliorate the detrimental effects of salt stress (Wang et al., 2011 and Imtiaz et al., 2016), toxicity of manganese (Shi et al., 2005), boron (Gunes et al., 2007) and cadmium (Shi et al., 2010) by altering the antioxidant enzyme activities; however more investigations are still needed. Silicon accumulates on walls of epidermal cells of different plant parts such as stem, leaf sheath and hull especially in monocots (Parven and Ashraf, 2010). Silicon increases the resistance of plants against diseases and insects, regulates the uptake of other ions by plants (Kaerlek, 2012) and decreases plant transpiration (Yoshida et al., 1959). The dominant form of silicon in soil solution is silicic acid $\left(\mathrm{H}_{4} \mathrm{SiO}_{4}\right)$ with concentration ranges from 0.1 to $0.8 \mathrm{mM}$ at $\mathrm{pH}$ below 9 (Lindsay, 1979; Ma \& Takahashi, 2002), while in plant tissues silicon exists as hydrated silica $\left(\mathrm{SiO}_{2} \cdot \mathrm{nH}_{2} \mathrm{O}\right)$ (Wainwright,

*Corresponding author: E-mail address: alshaaltarek@gmail.com; Telephone: (+2) 01066908917

DOI: $10.21608 /$ ejss.2017.891.1098

C2017 National Information and Documentation Centre (NIDOC) 
1997). The silica content in plants depends mainly on the sources of silicon as well as the ability of soil to supply silicon to the plants. Many plants, particularly graminaceous crops, absorb silicon in high quantities from soil during its life cycle (Epstein and Bloom, 2005 and Tamai \& Ma, 2003). The uptake of silicon by plants relies on many soil factors, particularly soil $\mathrm{pH}$ which affects the solubility of silicon in soil solution (Jones and Handreck, 1967) and low pH makes silicon more soluble in the form of silicic acid. Therefore, in alkaline soils, plants lack silicon supply. Incorporation and decomposition of plant residues into soils is considered one of the main mechanisms to compensate the removed silicon by plant uptake and keep adequate silicon concentration in soil solution (Lucas et al., 1993). However, nowadays farmers stopped to landfill the plant residues into the soils resulting in a decline in soil silicon content and causing a reduction in crop yields (Savant et al., 1997). The current study aimed to answer the following two questions; firstly, how does NS influence seed germination of common bean? Secondly, what is the role and importance of NS for development and growth of common bean plants?

\section{Materials and Methods}

\section{Germination experiment}

This experiment was performed to investigate the effect of NS on seed germination of common bean (Phaseolus vulgarisvar. strabic). In order to fulfil this aim, four elevated doses of NS were prepared using synthesised hydrophilic amorphous NS (Aerosil 300 produced by Evonik Industries, Germany). Used NS is characterized by specific surface area $\left(270-330 \mathrm{~m}^{2} \mathrm{~g}^{-1}\right), \mathrm{pH}$ (3.7$4.5)$, and mean diameter (10 nm). NS suspensions were prepared using distilled water to maintain concentrations of 100, 200, 300, and $400 \mathrm{mg} \mathrm{L}^{-1}$, and distilled water was applied as a control, these concentrations were equivalent to $1.66 \mathrm{mM}, 3.32$ $\mathrm{mM}, 4.99 \mathrm{mM}$, and $6.65 \mathrm{mM}$, respectively. Seeds of common bean were washed thoroughly with distilled water then immersed in hypochlorite solution $10 \%$ for $5 \mathrm{~min}$ for surface cleaning before the experiment. A $15-\mathrm{cm}$ diameter sterilized petri dishes were used to germinate the seeds of common bean in a completely randomized design (CRD) with three replicates. Filter papers were placed in the petri dishes. Seeds of each treatment were first soaked in NS solution (with the same concentration as applied in its NS treatment) for $4 \mathrm{hr}$ before transplanting, and then 15 seeds of common bean were distributed equally on doubled filter paper. $15 \mathrm{ml}$ of each NS treatment was transferred into petri dish. All petri dishes were sealed well to prevent filter paper drying and maintained moist and wet across the experiment for 10 days. All petri dishes were placed in dark place with room temperature of $23 \pm 2 \mathrm{C}^{\circ}$. Daily count of germinant was done from the onset of germination up to 10 days thereafter with a minimum length of $2 \mathrm{~mm}$ emergent radicle. At the end of the experiment, fresh and dry masses were taken for each replicate. Germination indicators were calculated as follows:

a) Final germination percentage (FGP) was computed as percentage (Ranal and Santana, 2006) using the formula:

$$
\mathrm{FGP}=\left[\frac{\mathrm{TNG}}{\mathrm{TNP}}\right] * 100
$$

where, FGP = final germination percentage; $\mathrm{TNG}$ $=$ total number of germinated seeds; and TNP = total number of planted seeds.

b) Mean germination time (MGT) was calculated by the formula cited by Mauromicale and Licandro (2002) given below:

$\mathrm{MGT}=\sum\left(\frac{n i * t i}{n i}\right)$

where, $\mathrm{MGT}=$ mean germination time; $\mathrm{ni}=$ the number of germinated seeds on day ti; $\mathrm{ti}=$ the number of days during the germination period (between 0 and 10 days). The mean germination time was used to evaluate seedling emergence.

c) Germination speed (GS) was computed as described by Czabator (1962) using the formula presented below:

$\mathrm{GS}=\sum\left(\frac{n i}{t i}\right)$

where, GS = germination speed; ni = the number of germinated seeds on day $\mathrm{ti} ; \mathrm{t} i=$ the number of days during the germination period (between 0 and 10 days).

d) Vigour index (VI) was calculated using the formula of Kharb et al. (1994), as follows:

$\mathrm{VI}=\left[\frac{\mathrm{SDM}(\mathrm{g}) * \mathrm{GP}}{100}\right]$

where, VI = vigour index; SDM = seedling dry mass $(\mathrm{g}) ; \mathrm{GP}=$ germination percentage.

\section{Greenhouse experiment}

The aim of this experiment was to monitor the development and the growth dynamic of common bean seedlings within the first three weeks after 
germination. Therefore, a plastic pot $(5 \mathrm{~cm} \times 5 \mathrm{~cm}$ $\mathrm{x} 8 \mathrm{~cm}$ ) was filled with $115 \mathrm{~g}$ of nursery mixture comprising of sand and peat moss at 1:1 ratio with a saturation percentage of $80 \%$. The seeds of common bean were washed thoroughly with distilled water before soaking in NS suspension for four $\mathrm{hr}$ according to their treatment before sowing. One seed per each pot was covered by 1 $\mathrm{cm}$ layer of growth mixture (sand and peatmoss), and irrigated by distilled water during the experiment to keep it wet at almost $65 \%$ from its saturation percentage. The pots were placed in greenhouse with average daily temperature of $24 \pm 2 \mathrm{C}^{\circ}$. NS treatments were $0,100,200,300$, and $400 \mathrm{mg} \mathrm{L}^{-1}$ of NS suspensions, which were equivalent to $0,1.66 \mathrm{mM}, 3.32 \mathrm{mM}, 4.99 \mathrm{mM}$, and $6.65 \mathrm{mM}$, respectively. Each pot received $100 \mathrm{ml}$ of its treatment of NS suspension. The NS dose was divided on a weekly basis to, $50 \%$ (50 $\mathrm{ml})$ before planting and second $50 \%(50 \mathrm{ml})$ one week later. All measurements of shoot length, root length, and dry shoot and root masses were taken weekly for three weeks.

\section{Statistical analysis}

Data analysis was performed using Microsoft Excel 2010 (mean values and standard deviation) from two individual experiments, and the statistical analysis was conducted using the XLSTAT software package. When a significant difference was observed between treatments, multiple comparisons were made by the Fisher test. Significant differences were accepted at the level $p<0.05$.

\section{Results and Discussion}

The final germination percentage (FGP) of common bean seeds was increased by using NS doses. All treatments of NS $(100,200,300$, and $400 \mathrm{mg} \mathrm{L}^{-1}$ ) enhanced the values of FGP against control. Significant differences of FGP among NS treatments as well as compared to control were found (Table 1). Addition of $100 \mathrm{mg} \mathrm{L}^{-1}$ of NS was enough to accelerate the growth of common bean seeds in comparison to control treatment (distilled water) which had the lowest FGP (82.3\%), while the highest value of FGP (97.7\%) was found at the treatment of $300 \mathrm{mg} \mathrm{L}^{-1}$ of NS. The optimum concentration of NS seemed to be $300 \mathrm{mg} \mathrm{L}^{-1}$, because it did enhance the seed germination, while lower induction of seed germination $(91.0 \%)$ was noticed at the highest concentration (400 $\mathrm{mg} \mathrm{L}^{-1}$ of NS).

The calculated values of mean germination time (MGT) of common bean seeds under elevated
NS levels are depicted in Table 1. Clearly, results showed that treated seeds with NS germinated in a shorter time than untreated seeds. While control seeds needed 4.27 days to germinate, all treated seeds with different NS concentrations germinated in almost 3.46 days and the shortest MGT was 3.31 days when seeds treated with 300 $\mathrm{mg} \mathrm{L}^{-1}$ of NS.

Data of germination speed (GS) reflected the great influence of added NS on seed germination of common bean (Table 1). Significant differences of GS values between treated seeds and untreated seeds were calculated. While control treatment resulted in GS of $24.9 \%$ per day, the NS treatment of $300 \mathrm{mg} \mathrm{L}^{-1}$ recorded GS of $36.2 \%$ per day as the highest measured value. However, treating seeds with NS even by $100 \mathrm{mg} \mathrm{L}^{-1}$ as the lowest dose enhanced the GS recording $30.2 \%$ per day against $24.9 \%$ per day for seeds received zero NS concentration.

Significant differences of vigour index (VI) were observed among NS treatments and the control. Furthermore, a considerable increase in VI was noticed when different concentrations of NS were applied (Table 1). A gradual increase in VI was found with increasing NS doses up to 300 $\mathrm{mg} \mathrm{L}^{-1}$ which had the highest value of VI (20.2). Although, $400 \mathrm{mg} \mathrm{L}^{-1} \mathrm{NS}$ recorded lower VI (18.6) than $300 \mathrm{mg} \mathrm{L}^{-1}$ but it was higher than other NS treatments and the control. However, these results of VI clearly showed that NS had a considerable effect on vigorousness of common bean seedlings; where seeds with high VI are considered vigorous. From results mentioned and discussed above, NS significantly induced and increased the germination of common bean seeds. Consequently, data of both fresh and dry masses of seedlings are consistent with those recorded for seed germination. Fresh mass increased with adding NS even at the lowest dose $\left(100 \mathrm{mg} \mathrm{L}^{-1}\right)$ compared to the control. The highest fresh mass was $1.080 \mathrm{~g}^{\text {germinant }}{ }^{-1}$ at the treatment of $300 \mathrm{mg} \mathrm{L}^{-1}$. The differences of fresh mass between control seedlings (zero NS) and treatments of NS were significant. Similarly, the effect of NS on dry mass of germinated seeds was in the same way as fresh mass. Highest dry mass $\left(0.207\right.$ g germinant $\left.^{-1}\right)$ was also noticed at the treatment of $300 \mathrm{mg} \mathrm{L}^{-1}$ where the lowest dry mass $\left(0.174 \mathrm{~g}\right.$ germinant $\left.{ }^{-1}\right)$ was measured at the control. However, all doses of NS had higher values of dry mass versus untreated seeds (Table 1).

Root dry mass of seedlings treated with NS was higher than that derived from untreated seedlings 
TABLE 1. Influence of elevated nano-silica concentrations on germination parameters of common bean (Phaseolus vulgaris)

\begin{tabular}{c|cccccc}
\hline $\begin{array}{c}\text { Nano-silica } \\
\left(\mathbf{m g L}^{-1}\right)\end{array}$ & $\begin{array}{c}\text { Fresh Mass } \\
\left.\text { (g germinant }^{-1}\right)\end{array}$ & $\begin{array}{c}\text { Dry Mass } \\
\left.\text { (g germinant }^{-1}\right)\end{array}$ & $\begin{array}{c}\text { FGP }^{\mathbf{1}} \\
\mathbf{( \% )}\end{array}$ & $\begin{array}{c}\mathbf{M G T}^{\mathbf{2}} \\
\mathbf{( d a y})\end{array}$ & $\begin{array}{c}\mathbf{G S}^{\mathbf{3}} \\
(\mathbf{\%} / \mathbf{d a y})\end{array}$ & VI $^{\mathbf{4}}$ \\
\hline 0 & $0.914 \mathrm{~b}$ & $0.174 \mathrm{~b}$ & $82.3 \mathrm{c}$ & $4.27 \mathrm{a}$ & $24.9 \mathrm{c}$ & $14.3 \mathrm{~d}$ \\
100 & $1.055 \mathrm{a}$ & $0.181 \mathrm{~b}$ & $84.7 \mathrm{bc}$ & $3.33 \mathrm{~b}$ & $30.2 \mathrm{~b}$ & $15.4 \mathrm{~cd}$ \\
200 & $1.070 \mathrm{a}$ & $0.195 \mathrm{ab}$ & $89.0 \mathrm{bc}$ & $3.46 \mathrm{ab}$ & $31.5 \mathrm{~b}$ & $17.3 \mathrm{bc}$ \\
300 & $1.080 \mathrm{a}$ & $0.207 \mathrm{a}$ & $97.7 \mathrm{a}$ & $3.31 \mathrm{~b}$ & $36.2 \mathrm{a}$ & $20.2 \mathrm{a}$ \\
400 & $1.025 \mathrm{a}$ & $0.204 \mathrm{a}$ & $91.0 \mathrm{ab}$ & $3.36 \mathrm{~b}$ & $33.3 \mathrm{ab}$ & $18.6 \mathrm{ab}$ \\
\hline
\end{tabular}

${ }^{1} \mathrm{FGP}=$ final germination percentage $(\%),{ }^{2} \mathrm{MGT}=$ mean germination time (day), ${ }^{3} \mathrm{GS}=$ germination speed $(\% /$ day $),{ }^{4} \mathrm{VI}$ =vigour index.Different letters in same column show significant differences among each group of treatments according to Fisher's test at $p<0.05$.

(Fig. 1). Among all NS treatments, $300 \mathrm{mg} \mathrm{L}^{-1}$ of NS enhanced more the growth of common bean seedlings. At the end of the experiment, control seedlings had root dry mass of $0.107 \mathrm{~g}$ seedling ${ }^{-1}$, while $0.207 \mathrm{~g}$ seedling $^{-1}$ dry mass of root was found at NS treatment of $300 \mathrm{mg} \mathrm{L}^{-1}$. Likewise, the measured values of shoot dry mass were similar to what was found and explained of root dry mass previously (Fig. 1). The highest value of shoot dry mass was denoted when NS was applied with the concentration of $300 \mathrm{mg} \mathrm{L}^{-1}$. Meanwhile, $0.983 \mathrm{~g}$ seedling $^{-1}$ of shoot dry mass was weighted at 300 $\mathrm{mg} \mathrm{L}^{-1} \mathrm{NS}$, control seedling had shoot dry mass of $0.550 \mathrm{~g}$ seedling $^{-1}$.

The length of root system and the shoot part of the studied seedlings are shown in Fig. 2. Also, the seedlings features during the experiment can be seen in Fig. 3. Length of root system reached the maximum length $(33.83 \mathrm{~cm})$ when NS added by $300 \mathrm{mg} \mathrm{L}^{-1}$ and the control plant had root length equal to $25.50 \mathrm{~cm}$. Values of shoot length were consistent with those of root system, showing higher values of shoot length than the control plant due to adding NS to the growth medium. All NS treatments had higher values of shoot and root length of common bean plants conversely to plants which received zero NS (Fig. 2). Shoot length was $11.08 \mathrm{~cm}$ at the end of the experiment under the treatment of $300 \mathrm{mg} \mathrm{L}^{-1}$, while control plant recorded the shortest shoot length $(9.79 \mathrm{~cm})$.

Seed germination is the most crucial stage in plant life and it determines whether the crop productivity will be successful or not (Bhattacharjee, 2008). Also, it depends on genetic

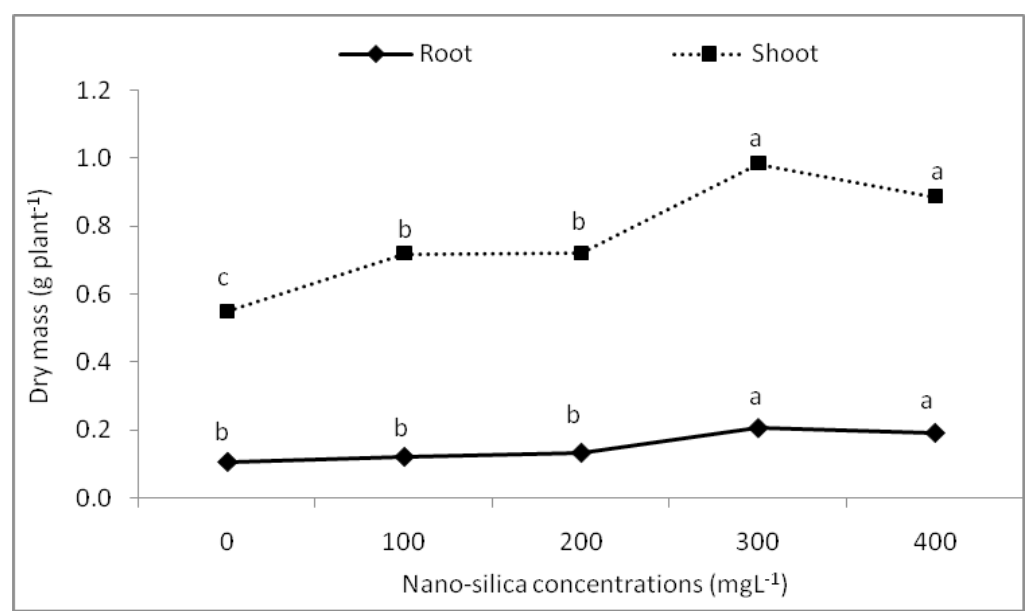

Fig. 1. Root and shoot dry mass of common bean increases in respond to using elevated nano-silica doses as a result of producing vigorous seedlings of common bean after treating seeds with nano-silica. Treatment of 300 $\mathrm{mg} \mathrm{L}^{-1}$ of nano-silica clearly recorded the highest values of root and shoot dry mass compared to control and other nano-silica levels.

Different letters over column with the same shading degree show significant differences among each group of treatments according to Fisher's test at $\mathrm{p}<0.05$

Egypt. J. Soil. Sci., 57, No. 4 (2017) 


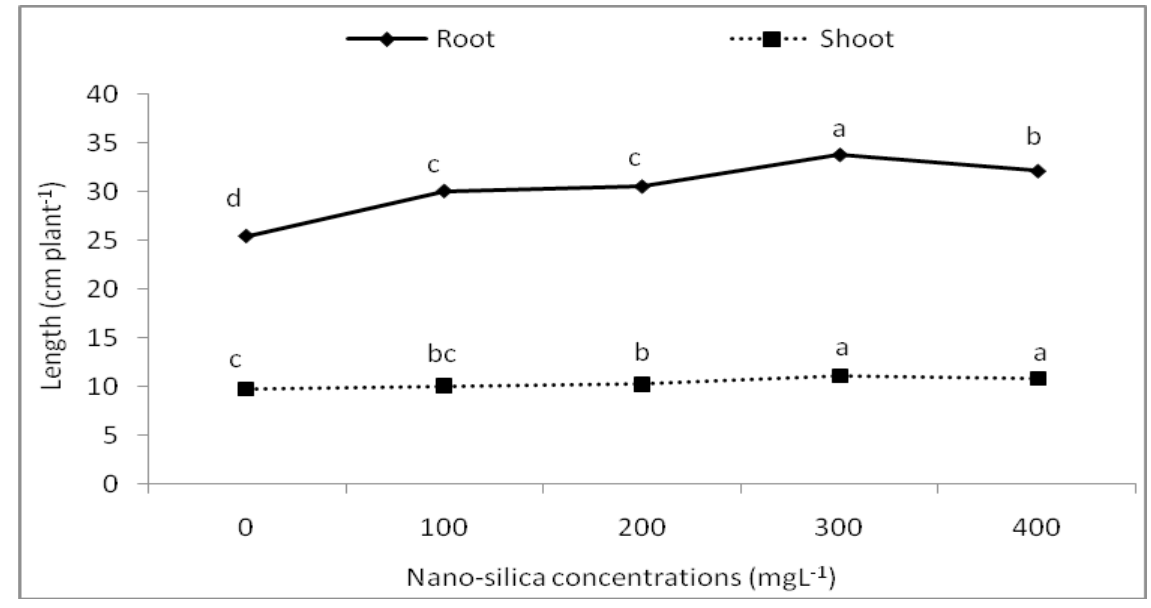

Fig. 2. Root and shoot length of common bean increases with adding nano-silica up to $400 \mathrm{mg} \mathrm{L}^{-1}$ showing that 300 $\mathrm{mg} \mathrm{L}^{-1}$ of nano-silica had the highest numbers among nano-silica treatments and control due to the role of nano-silica to accelerate seed germination and decrease evapotranspiration of plants.

Different letters over column with same shading degree show significant differences among each group of treatments according to Fisher'stest at $\mathrm{p}<0.05$.
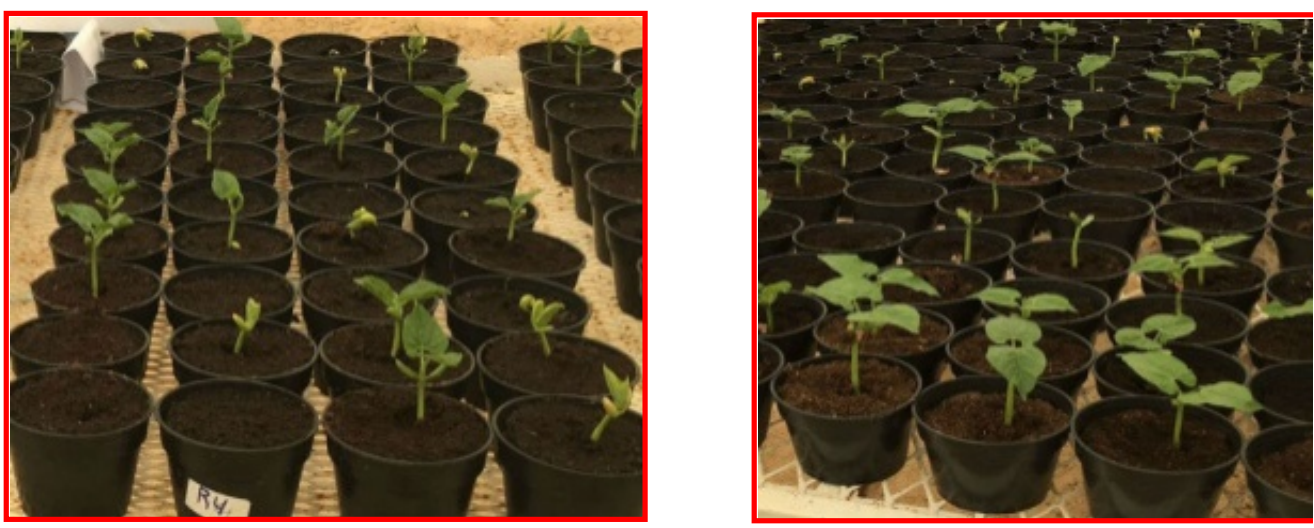

Fig. 3. Common bean plants on $7^{\text {th }}$ day from plantation growing on $400 \mathrm{mg} \mathrm{L}^{-1}$ nano-silica (B) versus control (A). The photo shows that nano-silica enhanced the growth of common bean, where treated seedlings with nanosilica were more vigorous than untreated seedlings.

factors and many ecological conditions such as depth, light, temperature, humidity, and salinity. Our observed results of FGP are consistent with other obtained results from different crops. Lu et al. (2015) cited that $5 \mathrm{~g} \mathrm{~L}^{-1}$ of NS increased FGP of tomato by $70.33 \%$ compared to the control. Also, NS was found to increase seed germination of maize by (2-11\%) when added to seeds in in vitro experiment (Yuvakkumar et al., 2011), and NS treatment of $300 \mathrm{mg} \mathrm{Kg}^{-1}$ denoted the highest germination percentage as found in our current study. Also, NS had good effect on germination of rice seeds as explained by Nair et al. (2011), they reported that the presence of silica nanoparticles had better impact on seed germination of rice and no toxicity symptoms of NS were noticed on emerged seedlings of rice. This indicated that NS had only positive effects on seed germination of different crops without any fears of phytotoxicity. FGP alone does not explain the rabidity of germination; it just gives the final extent (AlMudaris, 1998). So, germination speed and its daily distribution can be used to judge the efficacy of agronomic treatments employed to enhance the seed germination. MGT shows the average time that seed needs to start and finish its germination. The shorter the MGT is the faster the germination process of seed populations is. In the current investigation, MGT was diminished by $22.5 \%$ compared to the control; this meant that 
common bean seeds needed one day less for entire germination versus the control under almost all NS levels. The present results are supported by the earlier findings of Suriyaprabha et al. (2012), they investigated the effect of different silica sources on seed germination of maize (Zea mays L). They reported that NS particles enhanced MGT of maize seeds, while $\mathrm{Na}_{2} \mathrm{SiO}_{3}$ decreased it. Both micro$\mathrm{SiO}_{2}$ and $\mathrm{H}_{4} \mathrm{SiO}_{4}$ had insignificant effect on MGT. Azimi et al. (2014) denoted that using NS by the concentration of $40 \mathrm{mg} \mathrm{L}^{-1}$ reduced the MGT of tall wheat grass seeds to 5.23 days as the lowest needed a period for completing germination. GS expresses the percentage of germinated seeds per day during the germination period. As mentioned above, NS decreased the time needed for seed germination of common bean by almost one day than control seeds. This was reflected, of course, on GS values as an increase of $45.4 \%$ was found at the treatment of $300 \mathrm{mg} \mathrm{L}^{-1}$ of NS in comparison with control. This result proves the considerable effect of NS on the tested seed germination of common bean. In addition, Khalaki et al. (2016) found that NS enhanced and increased GS of Thymus kotschyanus under laboratory conditions. VI of seedlings is one of the most important physiological seed properties in seed production as considered by technologists and industrialists besides its being an important tool for calculating the percentage of fertile seed, VI also reveals the capability of those seeds which produce strong seedlings with longer root and shoot compared to those seedlings derived from the same seed lot especially when they grow under different abiotic stresses (Marcos-Filho, 2015). The importance of VI comes also from its ability to visualize and clarify whether seedlings after germination will keep growing or not, because in some cases germination happens when optimal growth conditions are attained, but maybe seedlings later will not be able to keep growing and complete their life cycle. Results derived from the current experiment showed that VI values increased significantly with adding NS to nursery media of common bean seeds. The highest increase (41.3 $\%$ compared to control) was found when NS was added by $300 \mathrm{mg} \mathrm{L}^{-1}$. The current results agreed with those cited by Azimi et al. (2014), who found that VI of tall wheatgrass seeds increased by 120 $\%$ compared to the control after treating the seeds by $40 \mathrm{mg} \mathrm{L}^{-1} \mathrm{NS}$. Among different concentrations of NS ranged from 1-10 $\mathrm{g} \mathrm{L}^{-1}$, treatment of $7 \mathrm{~g} \mathrm{~L}^{-1}$ yielded the highest VI relative to the control ( $\mathrm{Lu}$ et al., 2015). Our observed data concerning shoot and dry masses of common bean seedlings were similar to those cited by Siddiqui and Al-Whaibi (2014), who said that NS enhanced fresh and dry weights of tomato, also the same result was reported by Suriyaprabha et al. (2012) concerning maize. Conversely, Lu et al. (2015) did not find any significant differences in fresh and dry masses between tomato seedlings treated and untreated by NS.

Silicon is considered the only element which is able to induce the tolerance of plants to multiple stressors (Gengmao et al., 2015) due to its unique physicochemical properties. Therefore, based on its nano size, NS can easily cross the walls and penetrate the seed cover layer causing changes in the physicochemical reactions that take place in the seed and activate the embryo's growth even under both biotic and abiotic stresses particularly salinity and drought. For instance, Zheng et al. (2005) found that nanotitania particles improved the germination of the treated seeds compared to the control based on nano size of nanotitania particle to penetrate seed cover layer easily. They also mentioned another possible reason for the effect of nanotitania on seed germination. After nanotitania gets into the seed, it will alert the oxidation-reduction reactions (Redox) by producing superoxide ion radical during germination which will help in removing the free radicals and thus increase the chance of seed to germinate. Also, the produced oxygen via this reaction as a by-product could be involved in respiration which takes place inside the seed and would promote the germination. This explanation could be supported by the results obtained by Gengmao et al. (2015), since they reported that adding potassium silicate with $0.5 \mathrm{~g} \mathrm{~L}^{-1}$ induced the activities of catalase and superoxide dismutase, demonstrating that silicon has a vital role in the activity of these two enzymes. Moreover, they also demonstrated that silicon has a potential role in protecting the photosynthetic apparatus because silicon maintained the integrity of plasma membrane by inhibiting the separation of plasma membrane from plasmolysis. Also, Yuvakkumar et al. (2011) clarified that NS can stimulate the seed germination of many plants as a result of its vital role in activation of some biochemical reactions which may lead to inhibition of abscisic acid production and enhancement of gibberellin secretion to release the dormancy of seeds. In addition, the positive effect of NS on seed germination could be referred to the ability of seeds to absorb the NS particles and utilize 
them causing activation of seed germination (Suriyaprabha et al., 2012).

\section{Conclusion}

In agriculture, nanoparticles have proved its vital role particularly in plant nutrition, diseases protection, and soil improvement. Germination is a critical stage in plant life, and further growth and productivity depends mainly on the success germination process. In the present work, NS proved its significant importance for seed germination and growth of common bean, where NS enhanced the germination parameters and resulted in vigorous seedlings. All measured germination parameters such as FGP, MGT, VI, GS, and biomass of germinant were positively affected by NS having higher values compared to untreated seeds with NS. Among four elevated NS doses (i.e., 100, 200, 300, and $400 \mathrm{mg} \mathrm{L}^{-1}$ ) the treatment of $300 \mathrm{mg} \mathrm{L}^{-1} \mathrm{NS}$ had the highest values of germination indicators and vegetative properties. Based on these results, it could be concluded that $300 \mathrm{mg} \mathrm{L}^{-1}$ of NS suspension is the ideal concentration that common bean should be treated with under greenhouse conditions. The investigations on the mode of action of NS that affect the germination and growth of common bean are still somehow lacking, however, our results illustrate that NS can improve the germination and growth of common bean. This can be attributed to the nano size of silica which allows it to penetrate the seed cover layer causing changes in the physicochemical reactions in the seed and activate the embryo's growth giving vigorous seedlings.

\section{Acknowledgments}

The authors would like to thank Dr. M. ElGarawani from the Research Station in King Faisal University for his help and assistance during the experiment duration.

\section{Compliance with Ethical Standards}

Funding: This study was not funded.

\section{Conflict of Interest}

The authors declare that they have no conflict of interest.

\section{References}

Alexander, M. (1984) Ecology of rhizobuim. In Biological Nitrogen Fixation: Ecology, Alexander,
M. (Ed.), Technol. Physiol. 39-50. Plenum Press, New York.

Al-Mudaris, M.A. (1998) Notes on Various Parameters Recording the Speed of Seed Germination. Der Tropenlandwirt, BeiträgezurtropischenLandwirtschaft und Veterinärmedizin, 99. Jahrgang, Oktober 98, S. 141 - 154.

Azimi, R., Borzelabad, M.J., Feizi, H. and Azimi, A., (2014) Interaction of $\mathrm{SiO}_{2}$ nanoparticles with seed prechilling on germination and early seedling growth of tall wheatgrass (Agropyronelongatum L.). Polish. J. ChemTechnol. 16 (3), 25-29. Doi: 10.2478/pjct-2014-0045.

Bhattacharjee, S. (2008) Triadimefon pretreatment protects newly assembled membrane system and causes up-regulation of stress proteins in salinity stressed Amaranthus lividus L. during early germination. J. Environ. Biol. 29, 805-810.

Borém, A. and Carneiro, J.E.S. (1999) A cultura. In: Vieira C, Paulajr TJ, Borém A (Ed.). Feijão: aspectosgerais e cultura no estado de Minas Gerais. Viçosa: UFV, 13-17.

Czabator, F.J. (1962) Germination value: an index combining speed and completeness of pine seed germination. Forest Sci. 8, 386-396.

Epstein, E. and Bloom, A.J. (2005) Mineral nutrition of plants: principles and perspectives. 2nd ed. Sunderland (MA): Sinauer Associates, Sunderland, MA.

F.A.O. (2009) Production year book. Food and Agriculture Organization for the United Nations, Rome Italy.

Gengmao, Z., Shihui, L., Xing, S. et al (2015) The role of silicon in physiology of the medicinal plant (Lonicera japonica L.) under salt stress. Nature, Scientific Reports 5. doi.org/10.1038/srep12696.

Gunes, A., Inal, A. and Bagic, E.G. (2007) Silicon mediated changes of some physiological and enzymatic parameters symptomatic for oxidative stress in spinach and tomato grown in sodic - B toxic soil. Plant soil 290,103- 114. Doi: 10.1007/s11104-006-9137-9.

Imtiaz, M., M. S. Rizwan, M. A. Mushtaq, M. et al (2016) Silicon occurrence, uptake, transport and mechanisms of heavy metals, minerals and salinity enhanced tolerance in plants with future prospects: A review. J. Environ Manag. 183 (Part 3), 521-529. http://dx.doi.org/10.1016/j.jenvman. 2016.09.009.

Jones, L.H.P. and Handreck, K.A. (1967) Silica in soils, Egypt. J. Soil. Sci., 57, No. 4 (2017) 
plants, and animals p. 107-149. In A.G. Norman (Ed.) Advances in Agronomy. Vol. 19. Academic Press, New York.

Kaerlek, W. (2012) Effect of Silicon on Plant Growth and Drought Stress Tolerance, Master Thesis, Utah State University, USA.

Khalaki, M.A., Ghorbani, A. and Moameri, M. (2016) Effects of silica and silver nanoparticles on seed germination traits of Thymus kotschyanus in laboratory conditions. J. Rangeland Sci., 6 (3), 221-231.

Khan, W.D., Aziz, T. and Maqsood, M.A. et al (2016) Silicon: A Beneficial Nutrient Under Salt Stress, Its Uptake Mechanism and Mode of Action. In: Soil Science: Agricultural and Environmental. In: K.R. Hakeem et al. (Ed.), Soil Science: Agricultural and Environmental Prospectives, DOI 10.1007/9783-319-34451-5_12, pp:287-301. Springer International Publishing Switzerland

Kharb, R.P.S., Lather, B.P.S. and Deswal, D.P. (1994) Prediction of fieldemergence through heritability and geneticadvance of vigour parameters. Seed Sci. Technol. 22, 461-466.

Lindsay, W.L. (1979) Chemical Equilibria in Soils, p. 51-54. John Wiley \& Sons, New York.

Lu, M,M,D, De, Silva, D.M.R., Peralta, E.K., Fajardo A.N., Peralta, M.M. (2015) Effects of nanosilica Powder from rice hull ash on seed germination of tomato (Lycopersiconesculentum). Applied Res Develop. 5, 11-22.

Lucas, Y., Luizão, F.J., Chauvel, A. et al (1993) The relation between biological activity of the rain forest and mineral composition of soils. Science, 260, 521-523.

Ma, J.F. and Takahashi, E. (2002) Soil, Fertilizer, and Plant Silicon Research in Japan, $1^{\text {st }}$ ed. Elsevier, Amsterdam.

Marcos-Filho, J. (2015) Seed vigor testing: an overview of the past, present and future perspective.Sciagric. 72 (4), 363-374. http://dx.doi.org/10.1590/01039016-2015-0007

Mauromicale, G. and Licandro, P. (2002) Salinity and temperature effects on germination, emergence and seedling growth of globe artichoke. Agronomie 22,443-450.http://dx.doi.org/10.1051/agro: 2002011.

Moreno-Limón, S., Maiti, R.K. and Foroughbakhch, R. (2000) Genotypic variability in Phaseolus bean cultivars exposed to salinity at the germination stage. Crop Res. 19 (1),487-492.

Nair, R., Poulose, A.C. and Nagaoka, Y. et al. (2011) Uptake of FITC labeled silica nanoparticles and quantum dots by rice seedlings: effects on seed germination and their potential as biolables for plants. J. Fluoresc. 21, 2057-2068. Doi:10.1007/ s10895-011-0904-5.

Parven, N. and Ashraf, M. (2010) Role of silicon in mitigating the adverse effects of salt stress on growth and photosynthetic attributes of two maize (Zea mays L.) cultivars grown hydroponically. Pak. J. Bot. 42, 1675-1684.

Ranal, M.A. and Santana, D.G. (2006) How and why to measure the germination process? Revista Brasil Bot. 29,1-11.

Romero, A.O., Damián, H.M.A., Rivera, T.J.A. et al. (2013) The nutritional value of beans (Phaseolus vulgaris L.) and its importance for feeding of rural communities in Puebla-Mexico. Inter. Res. J. Biol. Sci. 2 (8), 59-65.

Savant, N.K., Datnoff, L.E. and Snyder, G.H. (1997) Depletion of plant-available silicon in soils: a possible cause of declining rice yields. Commun Soil Sci Plant Anal. 28, 1245-1252. http://dx.doi. org/10.1080/00103629709369870

Shi, G., Cai, Q., Liu, C. and Wu, L. (2010) Silicon alleviates cadmium toxicity in peanut plants in relation to cadmium distribution and stimulation of antioxidative enzymes. Plant Growth Regul. 61, 45. doi:10.1007/s10725-010-9447-z

Shi, X.H., Zhang, C.C., Wang, H. and Zhang, F.S. (2005) Effect of $\mathrm{Si}$ on the distribution of $\mathrm{Cd}$ in rice seedling. Plant Soil. 273, 53-60.doi:10.1007/ s11104-004-3920-2.

Siddiqui, M.H. and Al-Whaibi, M.H. (2014) Role of nano- $\mathrm{SiO}_{2}$ in germination of tomato (Lycopersicumesculentum seeds Mill.). Saudi J. Biol. Sci. 21, 13-17.http://dx.doi.org/10.1016/j. sjbs. 2013. 04.005

Suriyaprabha, R., Karunakaran, G. and Yuvakkumar, R. et al. (2012) Silica nanoparticles for increased silica availability in maize (Zea mays L.) seeds under hydroponic conditions. Curr. Nanosci. 8,1-7. Doi. 10.2174/157341312803989033

Tamai, K., Ma, J.F. (2003) Characterization of silicon uptake by rice roots. New Phytologist, 158, 431436.Doi: 10.1046/j.1469-8137.2003.00773.x

Egypt. J. Soil. Sci., 57, No. 4 (2017) 
Wainwright, M. (1997) The neglected microbiology of silicon: from the origin of life to an explanation for what Henry Charlton Bastian saw. Soc Gen Microbiol Quart. 24, 83-85.

Wang, X., Wei, Z., Liu, D. and Zhao, G. (2011) Effects of $\mathrm{NaCl}$ and silicon on activities of antioxidative enzymes in roots, shoots and leaves of alfalfa. Afr J. Biotechnol. 10, 545-549. Doi: 10.5897/AJB10.1353

Yoshida, S., Onish, Y. and Kitagishi, K. (1959) Role of silicon in rice nutrition. Soil Plant Food, 5, 127133.

Yuvakkumar, R., Elango, V. and Rajendran, V. et al (2011) Influence of nanosilica powder on the growth of maize crop (Zea mays L.). Inter Green Nanotechnol. 3,180-190.http://dx.doi.org/10.1080/ 19430892.2011.628581

Zheng, L., Hong, F., Lu, S. and Liu, C. (2005) Effect of nano- $\mathrm{TiO}_{2}$ on strength of naturally growth aged seeds of spinach. Biol. Trace Elem. Res. 104, 83-91. Doi: 10.1385/BTER: 104,1, 083

(Received: $10 / 4 / 2017$ ) accepted: 10 / 5 /2017) 